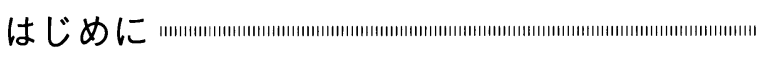

喫煙はがんの原因としての寄与危険度割合も大き く，また虚血性心疾患や脳卒中の重要な危険因子で もあり最近の研究ではメタボリックシンドロームと の関係も大きいことが確認されている1 3)。

一方，我が国では欧米に比し，いまだ男性の契煙 率が極めて高く，契煙習慣に対して効果的に介入で きる禁煙教育が望まれている。

本稿では我々の実施してきた，“1. 全喫煙者に対 する悉皆的な個別禁煙サポート4)” と近年の健診時 に実施している，“2．禁煙予備軍（希望者）に対す る個別禁煙サポート”の両者の個別禁煙教育の方法 並びにその効果について報告する。

\section{1. 定期健康診断時の全喫煙者を対象とした 個別禁煙指導}

(1) 対象：平成 10 年度に定期健康診断を受診し た 40 歳以上の男性従業員 847 名中の全契煙者（395 名）である。

（2）方法: 対象者を平成 10 年度に下記に示す個 別禁煙指導を実施する群（I 群）と呼気中 CO 濃度 測定と簡単な禁煙パンフレットを手渡す軽度の介入 群（II 群）の 2 群に分けた。II 群は翌年度に全員個 別禁煙指導を実施した。指導内容は中村正和らが開 発したプログラムに従い ${ }^{5)}$, 禁煙関心度別に 15 分間 個別指導を実施するもので, トレーニングを受けた 看護職が実施した。ただし、ニコチン代替療法は使 用していない。

〈I 群の主な指導内容〉

a ）ニコチン依存度チェック（FTQ 指数）

b ) 呼気中 CO 濃度測定 Smokerlyzer を使用 c ）尿中コチニン（ニコチン代謝産物）濃度測定

d）約 15 分の禁煙関心度別の個別カウンセリン グを実施。関心度の低いものには禁煙よりも 関心度のレベルアップを目指す指導内容

(3) 結果

I 群とII群におけるベースライン調査結果を表 1 に示す。両群とも準備期や関心期 II が極めて少な く, 約 90\%で関心がないか関心はあってもやめる気 がない（関心期 I ）であった。両群における 1 年後 の結果を図 1 に示す。I 群では禁煙実行者は $17.6 \%$ と II 群の $9.7 \%$ に比し有意に高かった。しかし， 1 年 後の禁煙成功率では, I 群で $8.8 \%$ と II 群の $5.9 \%$ に 比し高い傾向を認めたが有意差は認めなかった。

表 1 I 群と II 群における契煙関心度

\begin{tabular}{lccc} 
& & & $(\quad): \%$ \\
\hline & $\begin{array}{c}\text { I 群 } \\
(n=198)\end{array}$ & $\begin{array}{c}\text { II 群 } \\
(n=186)\end{array}$ & $\begin{array}{c}p \text {-value } \\
\left(\chi^{2} \text { 検定 }\right)\end{array}$ \\
\hline 無関心期 & $47(23.7)$ & $36(19.4)$ & \\
関心期 I & $126(63.6)$ & $126(67.7)$ & \multirow{2}{*}{ n.s. } \\
関心期 II & $18(9.1)$ & $17(9.1)$ & \\
準備期 & $7(3.5)$ & $7(3.8)$ & \\
\hline
\end{tabular}

無関心期：全く関心がない

関心期 I：関心はあるが禁煙する気はない

関心期 II ：関心があって 6 か月以内に禁煙したい

準備期 : 1 か月以内に禁煙したい

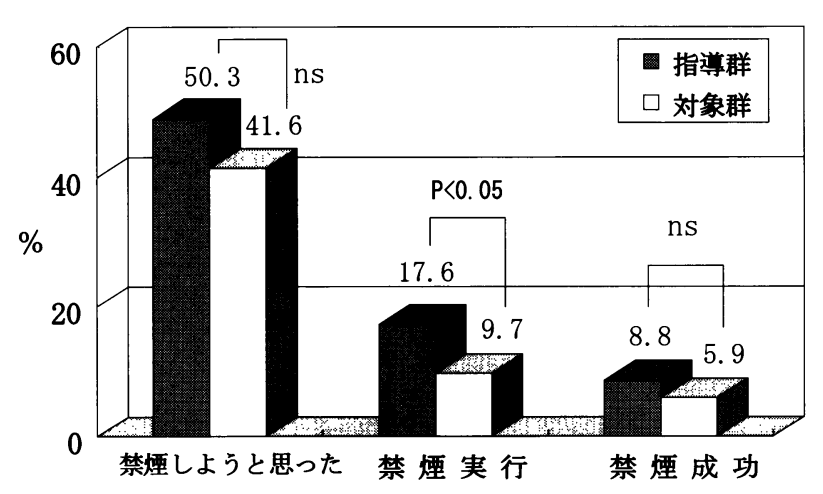

図 11 年後の調査結果 


\section{2. 禁煙予備軍に対する個別禁煙サポート ․แแㅔ}

定期健診時の契煙者への問診において，「できれ ばやめたい」と答えたものに対して，個別禁煙指導 を勧奨し希望者に実施しているものである。関心度 別では関心期 I , 関心期 II, 準備期のものが中心と なる。禁煙日設定者にはニコチン代替療法も併用す る。

（1）サポート内容

前記 I 群への指導内容 a )〜d）を実施して，更に 産業医による禁煙指導を実施する。そして希望者に ニコチンパッチも処方する。また，多くはニコチン ガムとの併用も実施している。すなわちパッチは起 床時から入浴前までとし, 起床直後の喫煙要求には ガムを半個かむことを認める。また，日中もどうし ても契煙要求が強くなったときは，ガム半個をかむ ことを許可している。

(2) フォローアップ

1）禁煙開始予定日の $1 \sim 2$ 週間後：電話による 禁煙開始, 継続の確認などの指導（看護職）

2) $2 \sim 4$ 週後禁煙外来再受診 : 指導とパッチの 処方

3 ） 3 か月後 : 電話による禁煙継続の確認（看護 職)

4）6か月後：メールによる自記式アンケート調 查

(3) 結果（平成 18 年度)

1）禁煙サポート人数：67 名

2 ）禁煙実施率 : $57.6 \%$

3 ）禁煙成功率（6 か月後）：36.8\%

考 察 8 年の経過を経て, 喫煙者全員への個別指導 (平成
10 年) と, 準備期, 関心期の希望者を対象とした個 別指導·禁煙治療（平成 18 年）を実施しその結果に ついて述べた。喫煙は個別の問題であり，禁煙治療 と平行して個別カウンセリングが効果的である。た だし，カウンセリングテクニックを身につけるため にある程度のトレーニングも必要である。

一般的には全く介入しない時の年間禁煙率が $3 \%$ であることを考えれば，前半の II 群（軽度介入）で 約 2 倍の $5.9 \%$, フル介入の 1 群で約 3 倍の $8.8 \%$ の 禁煙成功率は十分に高いと考えられる。無関心期 + 関心期 I が約 90\%の集団で, 少なくとも禁煙実行者 が $17.6 \%$ と II 群に比し有意に高く，ニコチン代替療 法なしの個別カウンセリングの効果を示唆するもの であった。この時代は不況・リストラの時代であり 再喫煙者が多くなった可能性も考えられた。

現在では社会の受動契煙防止対策が更に強化され ており，禁煙への関心度も増加しつつある。また, ニコチン代替療法の定着とともにバレニクリンも使 用可能となり, カウンセリングと合わせて高い禁煙 治療効率が期待されるようになってきた。

今後とも更に効果的な禁煙指導を展開していきた い。

\section{文 献}

1）大島明, 中村正和 : 喫煙とがん予防. CRC, 1(1):162172, 1992

2) Iso $\mathrm{H}$, et al. : Metabolic Syndrome and the Risk of Ischemic Heart Disease and Stroke among Japanese Men and Women. Stroke, 38 : 1744-1751, 2007

3) Nakanish N, et al. : Cigarette Smoking and the Risk of the Metabolic Syndrome in Middle-aged Japanese Male Office Workers. Ind Health, 43 : 295-301, 2005

4）廣部一彦, 山下千代子, 他 : 職場での個別健康教育の実践 と課題. 公采衛生, 66 : 14-17, 2002

5）増居志津子, 中村正和, 他 : 禁煙指導のための指導者卜 レーニングプログラムの開発. 日健教誌, 7 : 特別号, 256257, 1999 


\title{
Counseling for Smoking Cessation at the Annual Health Examination -Population Approach and High Risk Approach-
}

\author{
Kazuhiko HIRoBE
}

\begin{abstract}
We conducted the protocol focused on the private counseling of smoking cessation for all smokers at the annual health examination. Smokers were divided into two groups by semi-randomized. All candidates were checked density of carbon monoxide in their exhalations and Group 1 was undergone private counseling and Group 2 was only given a leaflet about smoking cessation.

We didn't use medication treatment for nicotine withdrawal.

Pooled quit rates at 6 months for Group 1 and Group 2 were $17.6 \%$ and $9.7 \%(p<0.05)$, and final success for smoking cessation at one year were $8.8 \%$ and $5.9 \%$ (ns) respectively. They say the smoking cessation rate without any intervention is about $3 \% /$ year and considering the low percentage of reserve for smoking cessation in both Group, interventions by private counseling might be effective for tobacco cessation.
\end{abstract}

